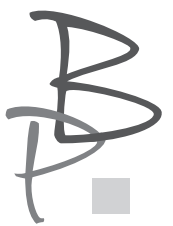

\author{
Tetiana Shevchenko* \\ Odeski Narodowy Uniwersytet im. Ilji Miecznikowa, Ukraina \\ https://orcid.org/0000-0003-4258-8773
}

\title{
Топологія Одеси в есеїстиці Б. Херсонського
}

Typology of Odessa in the essays of B. Khersonsky

Abstract: The article analyzes the topological peculiarities of the embodiment of Odessa in B. Khersonsky's essays from the perspective of the "essay of place" as a peculiar variation of the writer's literary platform with regards to their topological format, which is a continuation of verbal searches, established in other practices, the ones that are already established for the writer. Odessa is outlined through important topographic accents made by means of reflection, the author's personal attachment to topological realities rooted in the past as well as their experience, and to their attraction of theorizing the phenomenon of space itself as an object of reflection, a factor of identity. Attention is drawn to the artistic and intellectual side to experiencing the problems of Odessa the people who represent it or are associated with it in the work "The Patched Blanket" by B. Khersonsky. The complex socio-cultural, mythological, political, historical, religious, ethnic, 
linguistic and other facets of a city with more than 200 years of history are the switches to this experience, thus creating images and essays whose nature is cultural, historical, mythological and existential at the same time.

Keywords: B. Khersonsky, essay, topological, Odesa, "essay of place".

Аналіз сучасної письменницької есеїстики, в якій широко представлене поняття простору, створює привід виділити в ній окремий, відмінний від подорожнього есею вид, який, за аналогією до позиції Д. Соболєва ${ }^{1}$, пропонуємо назвати „есеєм місия”. Річ у тім, що топос стає живильною енергією рефлексивного типу літератури, відтак цей тип літератури, прив'язаний до конкретного топосу (екзистенційно зумовлений, продовжується в особі, яка його осмислює, виводить на певні узагальнення 3 огляду на топос у даний момент тощо), у сучасній українській літературі становить окрему вагому платформу, що має вже стійкі ознаки, позначені повторюваністю, варіативністю і наочною чисельністю. Дедалі більше митців свідомо чи несвідомо занурюються в певний простір горизонтально й вертикально, даючи йому нові імпульси в есеїстичний спосіб. I це не той випадок, як із романом місця, праобразом якого виступив роман мандрів. Природа цього феномену інша: мандрівний есей став продовженням рефлексивної творчості, де панівне місце відведене одному, фіксованому простору, котре постійно викликає бажання всебічного осмислення в історичних, культурологічних, філософських вимірах. Наочно виражений інтерес до певного місця, бажання усвідомити, збагнути його, відчути його дух перетворюють „есеї місця” на окремі художньо-рефлексивні феномени, де ракурс мислення, в якій „де” (ситуація осмислення) стає не менш важливою від ситуації „щ,о” (предмет осмислення). I в цьому „де” автор-есеїст розчиняється повністю, намагаючись і відчути, і зрозуміти, і усвідомити власне ставлення до місця, до себе, до свого занурення в ньому за допомогою усіх доступних для нього медитативних технік.

1 Д. Соболев, „Топофилия”: культурная география как жанр современной художественной прозы, „Международный журнал исследований культуры” 2011, № 4(5), s. 136-155. 
На відміну від подорожніх есеїв, які не такі численні в сучасному письменстві, есей місця посідає стійкі позиції в українському літературному просторі початку XXI століття, має чіткі, цілком конкретні ознаки, які описуємо нижче.

1. Місце в таких есея - творах, де панує думка над наративом чи описами, - $є$ надважливим, центральним в авторській репрезентації дійсності, воно стає предметом усебічних обсервацій - історичних, культурних, художніх, соціальних, філософських. „На лініях органічного перетину митця з місцем його мешкання й творчості виникає нова, невідома раніше реальність, яка не проходить ані за відомством мистецтва, ані за відомством географіі”2. Тож „есей місця” у цьому сенсі постає дискурсивною практикою-акумуляцією рефлексії, мистецтва й географії водночас. Топос тут об'єктивується, онтологізується автором, адже, як правило, він напряму з ним зв'язаний (етнічно, ментально, історично, біографічно, художньо тощо). У свою чергу, думка тут ословлюється за допомогою екзистенційних і спатіальних чинників, наділяється особливою модальністю. Просторово-індивідуальний континуум оприявнюється чинником, крізь який вимірюється все, про що б не писав автор-есеїст - чи то витоки власної романної творчості, чи сучасна мовна ситуація в Україні чи iï сутність як європейської держави. У цьому сенсі важко уявити всю творчість, наприклад, Т. Прохаська без прив'язки до івано-франківських реалій. Він навіть презентує нову метафоричну термінологію, як наприклад, „історична географія”, „географія роду”, „родинна географія”, „родова географія" тощо. Зважаючи на це, цілком прозорими стають думки про те, що „відчуття рідного і малої батьківщини є настільки надійним, що перестає бути суттєвим те, яка ця твоя батьківщина"”. Це ж стосується й творчості Ю. Андруховича, Ю. Іздрика, А. Любки, Є. Кононенко, К. Москальця, С. Процюка, І. Лучука, С. Грабаря, В. Махна, котра визначається багато в чому родо-географічним походженням митців і їх глибинною закоріненістю в певні ландшафти українського буття.

2. Описи самого місця в таких творах $є$ вторинними, на відміну, скажімо, від „роману місця”, в якому вони надважливі. В есеях, що їх виділяємо

3 Т. Прохасько, Одної і тої самої, Чернівці 2013, s. 80. 
як окремий тип, відсутні деталізовано прописані урбаністичні та інші локуси, тут зрідка можна зустріти „надлишок” візуальних та географічних деталей. Їх присутність мінімізована не через зменшення авторської уваги до них, а через інший характер завдань, які письменник ставить перед собою. В авторів „есеїв місця” специфічна задача: позиціонувати, концентрувати власні міркування в певних, наперед заданих локальних межах, однак не обмежитися місцем як тлом міркувань. Тут топологічні реалії постають векторами думок, задають тон, розставляють акценти, фіксують авторські есеми в наперед заданих межах, природа яких - історична, етнічна, міфопоетична, автобіографічна тощо. I часто ця фіксація розмислів відмінна від певних спатіальних стереотипів, наявних у читацькій свідомості. 3 огляду на це цілком природними постають уявлення про Львів як „місто-корабель” (Ю. Андрухович), Івано-Франківськ як „порт” (Т. Прохасько), Одесу як „середземноморське місто, (Б. Херсонський), Уріж та його околиці як місця „без ностальгії і зневаги” (Г. Пагутяк). Вони сприймаються не як власне художні образи, а як есеми-мислеобрази, природа яких - документальна й індивідуально-авторська водночас.

3. На відміну від ,роману місця”, в якому для авторів украй важливо деталізувати топос з метою якнайшвидшого впізнавання, вгадування його читачем (Д. Соболєв навіть у цьому контексті згадує так званий „літературний туризм”, суть якого - пошуки мандрівниками описаних у відомих романах місць під час особистої подорожі, скажімо, Петербургом, слідом за Ф. Достоєвським, чи Венецією - за Т. Манном) ${ }^{4}$. Есей місця таку мету не переслідує, адже місто - це лише тло міркувань, позбавлене матеріальної конкретності, воно має здебільшого лише ментальну етіологію. Навпаки, описуючи певний топос, автори зосереджуються на малознаних місцях, іншими словами, цю есеїстику з-поміж іншої прози визначає приватна спатіальність. Про екзотичність описів також не йдеться, радше про буденність. На певні просторові, украй інтимізовані, реалії припадає загострене „почуття місця” як згусток думки, осердя ментативних узагальнень. Місця, чимось знакові для автора, породжують несподівані ментативи, постаючи і джерелом натхнення, і локусом вербалізації мис-

4 Д. Соболев, „Топофилия”: культурная география как жанр современной художественной прозы, dz. cyt., s. 146. 
лення. Таким, наприклад, $є$ місток між берегами Бистриці Солотвинської в Івано-Франківську для I. Ципердюка (есей „Травень. Гори”), численні околиці Урожа, мало відомі навіть галичанам для Г. Пагутяк („Сентиментальні мандрівки Галичиною”), вулиця Олеся Гончара в Києві для С. Грабаря („Метаморфози”), маленькі вулички Ужгорода для А. Любки („Саудаде”). Ось, приміром, як С. Процюк відтворює вулицю Ольги Дучимінської в Івано-Франківську, знакове для нього місце, пов'язане із спогадами дитинства й юності:

Мені дуже легко бігати на стадіоні, де вулиця Ольги Дучимінської... Можливо, тому, що колись я відвідував ії з батьком. Батько їздив зі мною місцями, де витали нетривіальні енергії, принаймні, неспокій людського духу... Їздив, може, й сам не відаючи, що допомагає мені готуватися до виходу за межі узвичаєного (який це вихід і чи він загалом відбувся - інша царина...)... Тато залишився стояти. А я відірвався від землі - й полетів слідом за цією Жінкою, до довгих і світлих коридорів, де перехрещені всі покоління, де за царськими вратами заховалася стежка до іншого виміру...5.

4. Місце есеїстичної обсервації, іншими словами, топос, крізь призму якого автор дивиться на навколишню дійсність i, зважаючи на ментальні особливості якого вимальовує канву власних міркувань, важливу не тільки для есеїстичної творчості письменника, а й для основоположної - художньої, і часто $€$ iіï варіацією, продовженням. У двох видах творчості письменники апробують художні техніки відтворення топосу не як пасивного контексту, а як активної дієвої субстанції.

Так, галицький топос (львівський, ялівецький, івано-франківський, австро-угорський) складає підгрунтя більшості художніх творів Т. Прохаська („НепрОсті”, „Інші дні Анни”, „Лексикон таємних знань”). Він же опукло й системно прочитується в есеїстичних збірках цього письменника („Бо так Є”, „Одної і тої самої”, „ҒМ Галичина”, „Колії і залізниці”, „Порт Франківськ”, „Всі його фільми” тощо), демонструючи не просто картографічні реалії, упізнавані читачем, а й модус галицького мислення, закорінення в історію, традиції, міфологію, ментальність цього краю.

5 С. Процюк, Есеїстика/ Трикутник, Київ 2014, s. 255. 
Про наскрізність галицького топосу, про множинність досвіду ландшафтного мислення на його підставі однаковою мірою активно оприявненого в есеїстиці та художній прозі митця (обидві позначені „пульсуючою свідомістю”, демонструють „розірваний екзистенційний світ”, оповідь у них розгортається „мисленнєвими мовними конструкціями”, „топоніміка... перетинається з генетикою", відбувається демонстрація письма „3 виразною риторичною побудовою"7), чимало йдеться в дослідженнях О. Грищенка, Т. Гундорової, В. Лендєлової, Г. Лобановської, М. Титаренко тощо. Так, О. Грищенко пропонує поняття „геокомплекс" на позначення всієї творчості Т. Прохаська, зазначаючи неабияке тяжіння автора до ландшафтних експериментів: митець, досконально вивчивши франківську (i ширше - галицьку) топографію, наче розщеплює iї на частини у своїй творчості - есеїстичній та іншій. Самого ж митця дослідник називає ,письменником топографічного мислення"

Думка, що конструюється галицьким ландшафтом, питома ознака й творів Ю. Андруховича, Ю. Іздрика, С. Процюка тощо. Так, вагомий пласт творчості патріарха сучасної української літератури - це „галицький” (і ширше - карпатський) текст, щоразу прочитуваний у численних варіаціях як питомо український у романах „Рекреаціі”, „12 обручів”, „Таємниця”, так згодом і в збірках есеїв „Дезорієнтація на місцевості” чи „Лексикон інтимних місць”. Творчість Ю. Іздрика, по-особливому сполучувана $з$ топосм Івано-Франківська, постійно перепрочитується в художній („Станіслав і 11 визволителів”) та есеїстичній творчості („Флешка$2 \mathrm{~GB} ”)$. Львівський текст як „метафізичне краєзнавство” по-своєму маркує й творчість С. Процюка (роман „Інфекція” і, приміром, збірка есеїв „Тіні 3'являються на світанку").

Також про простір як формотворчий чинник авторської самоідентифікації, однаковою мірою проявлений в есеїстиці та прозі (поезії) митців, можна говорити на підставі „київського” тексту Є. Кононенко („Ко-

6 Т. І. Гундорова, Післячорнобильська бібліотека. Украйнський літературний постмодернізм, Вид. 2-е, випр. і доп., Київ 2013, s. 181-182.

7 Tamże, s. 177-184.

8 О. Грищенко, Ландшафтні експерименти Тараса Прохаська: від мініатюри до геокомплексу, „Науковий вісник МНУ імені В. О. Сухомлинського. Філологічні науки (літературознавство)" 2016, № 2 (18), s. 93. 
лосальний сюжет”; „Героїні та герої”), „урізького” тексту Г. Пагутяк („Захід сонця в Урожі”; „Сентиментальні мандрівки Галичиною”), „закарпатського” тексту А. Любки („Твій погляд, Чіо-Чіо-Сан”; „Саудаде”), „одеського” тексту Б. Херсонського („Сімейний архів”; „Клаптикова ковдра") тощо. У них автори, не відділяючи один тип творчості від іншого, онтологізують (оречевлюють, об'єктивують) певні топоси власним „я” за допомогою різноманітних форм рефлексії. У цьому оприявленні топосів простежується чинна для них традиція й новий варіант осмислення територій. Вони оприявнюють щоразу по-новому ті чи ті важливі узвичаєні просторові реалії через наповнення собою-митцем, з урахуванням того, що витоки, модуси, властивості власної свідомості слід шукати в тому ж таки топосі, який письменником репрезентується - в есеї чи романі. Порівняймо, наприклад, романний і есеїстичний тексти А. Любки:

Ужгород - західноукраїнський прихисток Півдня...Черепиця тут червона, а з дворів пахне гарячим хлібом, Уж під мостом мілкий, як жебрача кишеня, а чайки на воді підказують дурнуватим туристам, що за настроєм це містопорт, розмаїте і пахуче. Воно щебече всіма мовами і не прощає нікому, хто п'є слабку каву. Тут ростуть сливи і квіти, а надвечір вулицями лине музика з набережної, запрошуючи до непоспішливої променадия;

О п'ятій ранку ви будете єдиним господарем Ужгорода, ідеальним ужгородцем. Це той час, коли вулиці порожні, а денне світло лише насичує повітря, коли запах цвітіння дерев і квітів аж б'є в ніздрі, а свідомість легка, чиста й відкрита...Тоді йду порожніми вулицями, розглядаючи свічки дерев, дахи з черепиці й елементи декору будівель. Вулиці широкі, тоді відчуваєш, що колись старий Ужгород будувався як велике місто простору й можливостей; це тепер він перенаселений і затісний ${ }^{10}$.

5. Питома ознака „есею місця” - не просто закорінення в певні топологічні реалії, не просто ословлення території, а, насамперед, осмислення іiї своєрідності й важливості для людей, які іiі презентують, а відтак

9 А. Любка, Твій погляд, Чіо-Чіо-сан, Чернівці 2018, s. 108-109.

10 Tegoż, Спати з жінками, Чернівці 2014, s. 130-131. 
і оприявнюють певний тип мислення, відмінний від інших. Крім того, сам топос як важливий складник буття сучасної людини неодмінно стає предметом рефлексії, тож часто в есеїстиці такого типу можна знайти й чимало теоретико-публіцистичних узагальнень про це. Митці, презентуючи міркування очима представника певного топосу, часто-густо вдаються й до зовнішніх узагальнень про сутність території у житті людини минулого й сучасності, занурюючись у ці процеси зсередини, адже й самі є носіями свідомості певного топосу. Так, той же Т. Прохасько переконаний, що „початки нашого характеру безпосередньо пов’язані з нашим місцем...”11. Він же виводить код „персональної географії, складниками якої є історична географія, географія роду, родинна географія тощо:

Формою історії $\epsilon$ поступове переміщення на земній площині. Якщо я знаю, де я $\epsilon$, то мені необхідно знати, чому я тут $\epsilon$, як я прийшов туди, де зупинився. Погодившись бути подібним на інших, які тут теж зупинилися, прийшовши своїм складним шляхом, принісши його у нашу історію, яка стає спільною12.

Ю. Андрухович, посилаючись на Ш. Абдуллаєва, пише, що „місцевість користується людиною - iï зосередженістю, іiі перебуванням в оптичній меланхолії. Подібно до відображення у дзеркалі, місцевості необхідний сторонній погляд, аби вона 3'явилася і зрадила себе"13, а І. Лучук, зокрема, пише про „світоглядний мікрокосмос”, „буттєве самоусвідомлення”14 та „закоріненість у рідну землю” 15 , котра присутня на вербальному рівні. Приклади таких узагальнень можна знайти в більшості „есеїв місця”. Відтак метод топологічної рефлексії якнайкраще адаптований для аналізу цих письменницьких творів. Як зазначає В. Савчук, „топологія не покривається й тим більше не зводиться до ландшафту, географії і топографії, особливостей місця. У гуманітарному дискурсі топологія відсилає до більш

11 Т. Прохасько, Одної і тої самої, Чернівці 2013, s. 13.

12 Tamże, s. 87.

13 Ю. Андрухович, Дезорієнтаиія на місиевості, Івано-Франківськ 2006, s. 62.

14 І. Лучук, Сумніви сорокалітнього, Тернопіль 2008, s. 132.

15 Tamże, s. 133. 
суворого значення, яке набувається онтологічним його прочитанням"16. Він же акцентує на тому, що „рефлексія справжнього митця” a priori топологічна за своєю суттю, вона $є$,співвіднесення погляду з думкою і відповіддю власного тіла з його естетичним досвідом"17.

Усі ці та інші ознаки ,есею місця” виділяють його 3-поміж інших текстів-рефлексій у сучасній українській літературі.

Проаналізуємо у цьому сенсі своєрідність топологічних особливостей утілення певного простору крізь формат „есею місця” на прикладі творчості відомого одеського письменника Б. Херсонського, який себе позиціонує як український двомовний поет. Його збірка есеїстики „Клаптикова ковдра" побачила світ 2016 року, містить 17 есеїв українською й російською мовами. Сама назва збірки відсилає до розмаїття порушених проблем, як і постатей, назв, дат. На думку автора, відомого поета, лауреата численних літературних премій, сучасній людині властивий фрагментарний тип мислення: вона шукає себе одномоментно в історії, філософії, культурі, політиці, літературі тощо. Однак незмінними залишаються витоки цих пошуків, людське вкорінення в певний простір. Ним для письменника стає Одеса, котра прочитується у всьому, про що б він не писав: російсько-єврейська література („Про філологічний антисемітизм”), тяжіння до колекціонування в радянські часи (,Час збирати”), витоки поезії й сучасне студентство („На руїнах епохи”), викладацька робота й медична практика („Передостанні речі”) - він усе обчислює мірками одеського митця, людини, предки якої були одеситами, починаючи 3 середини XIX століття. „Одеський” текст есею формують фрагментарні й більш-менш деталізовані описи одеських краєвидів, розповіді про зустрічі з відомими й мало знаними одеситами чи тими, хто дотичний до цього південного міста, вкраплення віршів одеських поетів, фрагментів поезії про Одесу й Чорне море інших митців, додавання власних творів, наповнених південним і морським колоритом. $Є$ серед есеїв збірки і спеціально присвячені Одесі та іiі людям. Так, наприклад, власне пояснення „одеського міфу” подається в україномовному есеї „Одеський синдром”,

16 В. В. Савчук, Топологическая рефлексия, Москва 2012, s. 142.

17 Tamże, s. 158. 
в якому автор дає оригінальне трактування цього феномену, більшою мірою створеного за межами Одеси. Але міф осмислюється і крізь призму власної свідомості письменника й одесита, відтак висновки, створені есеїстом про цей міф, були б неможливими в іншому регіоні і в інших історико-географічних реаліях. Зокрема, автор пише:

Міф полягає, насамперед, у тому, що Одеса - абсолютно особливе місто, чужорідне тіло, кістка в горлі будь-якої держави, у складі якої б вона перебувала. Порто-франко, вільна зона (але зона!) - ось неосяжна мрія міста, минуле, яке вислизнуло назавжди. Одесити - братство, одна сім'я, незалежно від національності, релігії та ін. Можна сказати - Одеса, як Арбат у Окуджави - моя батьківщина, моя релігія ${ }^{18}$.

„Одеські есеї” Б. Херсонського щедро наповнені автобіографічним струменем: розповіді про навчання, медичну й літературну практику, важливі зустрічі й знайомство $з$ певними людьми та творами, дотичними до південного міста. Пишучи про болючі проблеми сьогодення, митець по-одеськи уникає категоричності, намагаючись назвати всі максимально можливі „за” й „проти” в складних ситуаціях. Це прочитується у більшості позицій, осмислюваних автором, навіть у позиціюванні себе як українського-російського-єврейського поета: уникаючи прямої відповіді, до якої з літератур автор себе зараховує, він обмежується лише лаконічним „кров визначає рівень літературних досягнень” 19 та міркуваннями про хворобливо розвинене відчуття "свого" й “чужого" 20.

На сторінках збірки ми не зустрінемо розлогих, деталізованих описів Одеси. Локації Південної Пальміри нечисленні й тим більше не екзотичні. Однак якщо вони зустрічаються, то постають украй інтимізованими, наповненими свідомістю самого автора, одесита в кількох поколіннях, як-от:

В тому будинку, де ми жили в Одесі, дійсно розташовувався ЧК. У дворі, де я грав дитиною, розстрілювали. Дія оповідання Бабеля "Фроїм Грач" від-

18 Z Б. Херсонський, Клаптикова ковдра, Київ 2016, s. 214.

19 Tamże, s. 301.

20 Tamże, s. 298. 
бувається саме в цьому будинку. На площі Потьомкінців, нині знову - Катеринінській. І я на власні очі бачив передсмертні написи на стінах, коли хлопчиськом десяти-дванадцяти років лазив по підвалах з китайським ліхтариком. Коли кажуть правду, складається враження штучності чи надуманості. Я часто помічав, що не буває приголомшливих надуманих фактів і почуттів: ти ніколи не вигадаєш і не відчуєш таких речей, які показує тобі реальність... 21 .

Тут же ми знайдемо традиційні вже для „есею місця” спроби теоретизувати топос як витоки мислення в дусі П. Вайля, що

існує не тільки дух часу (Zeitgeist), але й дух місця, геній місця. Іноді вони поєднуються (є таке бахтинське слово "хронотоп", воно завжди мені назву якогось стародавнього звіра). Це об'єднання передбачає внутрішню боротьбу не за життя, а за смерть. Стосовно Одеси, то перемогу явно здобув дух місця. що дивно для такого молодого і легкого міста, як Одеса22.

Зі сторінок збірки „Клаптикова ковдра” постає Одеса як геокультурний феномен, власне, він і визначає сутність ширшого поняття - „одеського тексту”, який „,фформований у культурній свідомості відомими літературними творами, що моделюють історично й ментально зумовлені картини одеського світу"23. На думку Н. Сподарець, феномен одеського тексту слід ідентифікувати через категорію одеського геокультурного й літературного простору 24 . Його сутність передають топоси й локуси Одеси, картини іiі історичного минулого, менталітет їі мешканців. Самі описи міста при цьому є вторинними: це швидше тло міркувань, певний засіб упорядкування думок і світоустрою. Саме це має місце в збірці „Клаптикова ковдра” Б. Херсонського: тут головним є художньо-інтелектуальний

21 Tamże, s. 339.

22 Tamże, s. 182-183.

23 Н. В. Сподарец, Литературная топология Одессы в исследованиях краеведов, [w:] Odessa $w$ literaturach stowiańskich. Studia, red. naukowa J. Ławski i N. Maliutina, BiałystokOdessa 2016, s. 89.

24 Tamże, s. 96. 
досвід переживання проблем Одеси та людей, які іï презентують чи з нею асоціюються. Важелями переживання цього досвіду постають складні соціокультурні, міфологічні, політичні, історичні, релігійні, етнічні, мовні тощо інкорпорації міста 3 понад 200-літньою історією, що й формують ціннісну, смислову призму укладання думок, стають підставою ïx ієрархії, засобом організації мислення, базисом створення образів та есем, природа яких культурно-історична, міфологічна та індивідуальноекзистенційна водночас. Вони зрозумілі насамперед вихідцям 3 цього міста, його „генію”, а також усвідомлюються тими, хто хоч раз побував в Одесі. У цьому сенсі варто навести думку про ментальну спорідненість міста й людини П. Вайля: „Зв’язок людини із місцем іiі мешкання - загадковий, але очевидний. Чи так: незаперечний, але таємничий. Управляє ним відомий ще давнім людям genius loci, геній місця, що пов'язує інтелектуальні, духовні, емоційні явища з їх матеріальним середовищем. Для людини нового часу головними $є$ точки докладання і прояву культурних сил 3 міста. Ї̈̈ вигляд визначається генієм місця"25.

Отже, „есей місця” стає своєрідною варіацією літературної платформи письменника у топологічному форматі, адже $\epsilon$ продовженням словесних пошуків, започаткованих в інших - традиційних для художнього письменства практиках. Його виокремлюють надважливі топографічні акценти, здійснені засобами рефлексії, авторська особиста, закорінена в минуле, прив'язаність до топологічних реалій і певний досвід їх переживання, тяжіння до теоретизації самого явища простору як об'єкта рефлексії, чинника авторської самоідентифікації. „Есей місця” вирізняється стійкою повторюваністю, варіативністю в письменницькій творчості: митець, звернувшись до нього одного разу, потім вдається до таких практик неодноразово за принципом кола чи спіралі, про що свідчать численні збірки есеїстики, в яких митці, як би вони цього не уникали, залишаються геніями одного місця, котре постійно варіюється й модифікується в тотожних дискурсивних практиках, однак не змінюється принципово і тим паче не зникає з поля зору митця. 


\section{Literatura}

Андрухович Ю., Дезорієнтація на місцевості, Івано-Франківськ 2006.

Вайль П. Л., Гений места, Москва 2006.

Грищенко О., Ландшафтні експерименти Тараса Прохаська: від мініатюри до геокомплексу, „Науковий вісник МНУ імені В. О. Сухомлинського. Філологічні науки (літературознавство)" 2016, № 2 (18).

Гундорова Т. І., Післячорнобильська бібліотека. Український літературний постмодернізм, Вид. 2-е, випр. і доп., Київ 2013.

Лучук І., Сумніви сорокалітнього, Тернопіль 2008.

Прохасько Т., Одної і тої самої, Чернівці 2013.

Процюк С., Есеїстика, Київ 2014.

Савчук В. В., Топологическая рефлексия, Москва 2012.

Соболев Д., „Топофилия": культурная география как жанр современной художественной прозы, „Международный журнал исследований культуры” 2011, № 4(5).

Сподарец Н. В., Литературная топология Одессы в исследованиях краеведов, [в:] Odessa w literaturach słowiańskich. Studia, ред. J. Ławski, N. Maliutina, Białystok-Odessa 2016.

Херсонський Б., Клаптикова ковдра, Київ 2016.

\section{Bibliografia}

Andrukhovych YU., Dezoriyentatsiya na mistsevosti, Ivano-Frankivs'k 2006.

Hryshchenko O., Landshaftni eksperymenty Tarasa Prokhas'ka: vid miniatyury do heokompleksu, „Naukovyy visnyk MNU imeni V. O. Sukhomlyns'koho. Filolohichni nauky (literaturoznavstvo)" 2016, № 2 (18).

Hundorova T. I., Pislyachornobyl's'ka biblioteka. Ukrayins'kyy literaturnyy postmodernizm, Vyd. 2-e, vypr. i dop., Kyyiv 2013.

Khersons'kiy B., Klaptikova kovdra, Kiív 2016.

Luchuk I., Sumnivy sorokalitn'oho, Ternopil' 2008.

Prokhas'ko T., Odnoyi i toyi samoyi, Chernivtsi 2013.

Protsyuk S., Yeseïstika, Kiív 2014.

Savchuk V. V., Topologicheskaya refleksiya, Moskva 2012. 
Sobolev D., "Topofiliya": kul'turnaya geografiya kak zhanr sovremennoy khudozhestvennoy prozy, „Mezhdunarodnyy zhurnal issledovaniy kul'tury” 2011, № 4(5).

Spodarets N. V., Literaturnaya topologiya Odessy $v$ issledovaniyakh krayevedov, [w:] Odessa w literaturach słowiańskich. Studia, red. J. Ławski, N. Maliutina, Białystok-Odessa 2016.

Vayl' P. L., Henyy mesta, Moskva 2006. 